\title{
Comparative study of vaginal hysterectomy and abdominal hysterectomy for enlarged uterus
}

\author{
Chandrika S. ${ }^{1 *}$, Kasinath Kosti $^{2}$ \\ ${ }^{1}$ Department of Obstetrics and gynaecology, ESIC Gulbarga, Karnataka, India \\ ${ }^{2}$ Department of Obstetrics and gynaecology, Sub District Hospital Aurangabad, Maharashtra, India
}

Received: 17 July 2016

Revised: 18 July 2016

Accepted: 09 August 2016

\author{
*Correspondence: \\ Dr. Chandrika S, \\ E-mail: drchandrika.s@gmail.com
}

Copyright: $\odot$ the author(s), publisher and licensee Medip Academy. This is an open-access article distributed under the terms of the Creative Commons Attribution Non-Commercial License, which permits unrestricted non-commercial use, distribution, and reproduction in any medium, provided the original work is properly cited.

\begin{abstract}
Background: Hysterectomy is the second most common gynecological surgeries performed. Maximum (70\% to $80 \%$ ) hysterectomies are done by abdominal route. Abdominal route provides good visibility and easy access to pelvic organs.

Methods: Randomized prospective comparative study was carried out to know the feasibility of vaginal hysterectomy in moderately enlarged uterus due to benign conditions and to compare operative complications and morbidity of vaginal and abdominal hysterectomy in moderately enlarged uterus due to benign conditions at Department of Obstetrics and Gynecology, at tertiary health care hospital during the period from October 2009 to September 2011.

Results: Out of 50 cases, 25 cases were subjected for abdominal hysterectomy and 25 for vaginal hysterectomy. Cases with moderately enlarged uterus up to 16 weeks due to benign condition were included in the study. Cases with uterus more than 16 weeks, previous pelvic surgeries, adnexal mass, prolapse and restricted mobility were excluded from our study

Conclusions: Bulk reducing techniques were used to remove the moderately enlarged uterus through vaginal route. Vaginal hysterectomy is invasive route, safe and feasible in cases with enlarged uteri up to 14 weeks due to benign causes.
\end{abstract}

Keywords: Vaginal hysterectomy, Abdominal hysterectomy

\section{INTRODUCTION}

Hysterectomy, abdominal or vaginal, total or subtotal laparoscopic assisted vaginal hysterectomy is by far the most frequently performed elective major operation in Gynaecology. ${ }^{1}$ It is said that the two are not competitive procedures but each has its own place in the operative armamentarium of the gynaecologist. As compared to three routes, vaginal hysterectomy should be the route of choice and laparoscopic assisted vaginal hysterectomy (LAVH) as an alternative because of long operating time, expensive without added benefits in terms of postoperative complications compared to vaginal hysterectomy. $^{2}$ Abdominal route is preferred for moderately enlarged uterus but with techniques like morcellation, bisection and coring even vaginal route has become easier for enlarged uterus. ${ }^{3}$ By using the vaginal route postoperative morbidity can be reduced and faster recovery can be ensured. ${ }^{4}$

In this prospective study we have operated patients with enlarged uterus up to 16 weeks by vaginal and abdominal route and studied feasibility of vaginal hysterectomy for enlarged uterus. Also we have compared operative time, operative complications, postoperative hospital stay and recovery in hysterectomy cases by abdominal and vaginal routes. An objective of the study was to study the 
feasibility of vaginal hysterectomy in moderately enlarged uterus due to benign conditions.

To compare operative complications and morbidity of vaginal and abdominal hysterectomy in moderately enlarged uterus due to benign conditions and postoperative hospital stay and recovery.

\section{METHODS}

Study setting: Present study was carried out in the Department of Obstetrics and Gynecology, at tertiary health care hospital during the period from October 2009 to September 2011.

Study design: The study was a randomized prospective comparative study of abdominal hysterectomy with vaginal hysterectomy with enlarged uterus. The feasibility of vaginal hysterectomy in moderately enlarged uterus was studied along with intra-operative complications, post-operative morbidity, post-operative hospital stay and recovery.

The study was carried out at the Department of Obstetrics and Gynecology, at tertiary health care hospital. A total of 50 cases were admitted to Gynecology ward requiring hysterectomy for enlarged uterus due to benign diseases for recruiting to this study. These 50 cases were randomly allocated into two groups using randomization procedure according to the type of surgery. Out of these 50 cases, 25 cases were subjected for total abdominal hysterectomy and 25 for vaginal hysterectomy.

\section{Inclusion criteria}

Following cases were included in our study
- Cases with enlarged uterus up to 16 weeks.

\section{Exclusion criteria}

Following cases were excluded from our study.

- Cases with uterine prolapse.

- Associated adnexal pathology.

- History of previous abdominal surgery or pelvic organ surgeries.

Uterus size more than 16 weeks.

\section{RESULTS}

In our study total 50 cases were subjected for hysterectomy by different routes of which 25 cases were subjected for abdominal hysterectomy and 25 for vaginal hysterectomy.

Table 1: Distribution of cases in abdominal and vaginal hysterectomy.

\begin{tabular}{|lll|l|}
\hline Group & $\begin{array}{l}\text { Abdominal N } \\
(\%)\end{array}$ & $\begin{array}{l}\text { Vaginal } \\
\text { N }(\%)\end{array}$ & $\begin{array}{l}\text { Total N } \\
(\%)\end{array}$ \\
\hline $\begin{array}{l}\text { No. of } \\
\text { cases }\end{array}$ & $25(50 \%)$ & $25(50 \%)$ & $50(100 \%)$ \\
\hline
\end{tabular}

Table 2: Age wise distribution of cases.

\begin{tabular}{|lll|}
\hline Group & $\begin{array}{l}\text { Mean } \\
\text { Age(years) } \pm \text { SD }\end{array}$ & p-value \\
\cline { 1 - 2 } Abdominal & $47.68 \pm 9.28$ & 0.8723, NS \\
\cline { 1 - 2 } Vaginal & $47.28 \pm 9.18$ & \\
\hline
\end{tabular}

Table 3: Parity wise distribution of cases in abdominal and vaginal hysterectomy.

\begin{tabular}{|llll|}
\hline Parity & Abdominal & Vaginal & Total \\
& N $(\%)$ & N $(\%)$ & N $(\%)$ \\
\hline Nuli-P1 & $02(08 \%)$ & $02(08 \%)$ & $04(08 \%)$ \\
\hline P2-P4 & $20(80 \%)$ & $21(84 \%)$ & $41(82 \%)$ \\
\hline P5-P7 & $03(12 \%)$ & $02(08 \%)$ & $05(10 \%)$ \\
\hline Total & 25 & 25 & $50(100 \%)$ \\
\hline Chi2 $=0.2244, \mathrm{p}=0.894$, NS & & & \\
\hline
\end{tabular}

Table 4: Indication wise distribution of cases in abdominal and vaginal group.

\begin{tabular}{|c|c|c|c|c|}
\hline Indications & Abdominal N (\%) & Vaginal N (\%) & Total N (\%) & p-value \\
\hline Fibroid & $16(64 \%)$ & $16(64 \%)$ & $32(64 \%)$ & \multirow{5}{*}{$\begin{array}{l}\text { Chi } 2=2.533 \\
p=0.639, \mathrm{NS}\end{array}$} \\
\hline Adenomyosis & $05(20 \%)$ & $03(12 \%)$ & $08(16 \%)$ & \\
\hline Endometrial hyperplasia & $03(12 \%)$ & $06(24 \%)$ & $09(18 \%)$ & \\
\hline Endometrial Polyp & $01(4 \%)$ & $00(0 \%)$ & $01(02 \%)$ & \\
\hline Total & 25 & 25 & 50 & \\
\hline
\end{tabular}


Table 5: Uterine size wise distribution in abdominal and vaginal group.

\begin{tabular}{|lllll|}
\hline Size of uterus (weeks) & Abdominal N (\%) & Vaginal N (\%) & Total N (\%) & P=value \\
\hline$<12$ weeks & $18(72 \%)$ & $20(80 \%)$ & $38(76 \%)$ & Chi2 $=0.4386$ \\
\hline$\geq 12$ weeks & $07(28 \%)$ & $05(20 \%)$ & $12(24 \%)$ & $\mathrm{p}=0.508$, NS \\
\hline
\end{tabular}

Table 6: Uterine weight wise distribution of cases in abdominal and vaginal group.

\begin{tabular}{|llll|}
\hline Weight of uterus (gm) & Abdominal N $(\%)$ & Vaginal N $(\%)$ & $\begin{array}{l}\text { Total } \\
\mathbf{N}(\%)\end{array}$ \\
\hline $100-150$ & $12(48 \%)$ & $12(48 \%)$ & $24(48 \%)$ \\
\hline $151-200$ & $04(16 \%)$ & $07(28 \%)$ & $11(22 \%)$ \\
\hline $201-250$ & $03(12 \%)$ & $02(08 \%)$ & $05(10 \%)$ \\
\hline $251-300$ & $03(12 \%)$ & $03(12 \%)$ & $06(12 \%)$ \\
\hline $301-350$ & $03(12 \%)$ & $01(04 \%)$ & $04(08 \%)$ \\
\hline Total & 25 & 25 & $50(100 \%)$ \\
\hline
\end{tabular}

Table 7: Intra-operative blood loss in abdominal and vaginal group.

\begin{tabular}{|llll|}
\hline $\begin{array}{l}\text { Intra-0perative } \\
\text { blood loss }(\mathrm{ml})\end{array}$ & $\mathbf{A}(\%)$ & $\mathbf{N}(\%)$ & $\begin{array}{l}\text { Total } \\
\mathbf{N}(\%)\end{array}$ \\
\hline $200-300$ & $11(44 \%)$ & $17(68 \%)$ & $28(56 \%)$ \\
\hline $301-500$ & $14(56 \%)$ & $08(32 \%)$ & $22(44 \%)$ \\
\hline Total & 25 & 25 & $100(100 \%)$ \\
\hline
\end{tabular}

Table 8: Mean blood loss in abdominal and vaginal group.

\begin{tabular}{|lll|}
\hline Group & $\begin{array}{l}\text { Blood loss }(\mathrm{ml}) \text { Mean } \\
\text { blood loss }(\mathrm{ml}) \pm \text { SD }\end{array}$ & p-value \\
\hline Abdominal & $326.2 \pm 35.30$ & 0.0097, HS \\
\hline Vaginal & $297.8 \pm 39.16$ & \\
\hline
\end{tabular}

Table 9: Operative time in abdominal and vaginal group.

\begin{tabular}{|lll|}
\hline Group & $\begin{array}{l}\text { Mean operative } \\
\text { time } \pm \text { SD (Minutes) }\end{array}$ & p-value \\
\hline Abdominal & $51 \pm 5.95$ & 0.0000, HS \\
\hline Vaginal & $65.4 \pm 8.28$ & \\
\hline
\end{tabular}

Table 10: Blood loss and operative time in comparison with size of uterus in abdominal and vaginal group.

\begin{tabular}{|llll|}
\hline $\begin{array}{l}\text { Sive of } \\
\text { uterus }\end{array}$ & Group & $\begin{array}{l}\text { Mean blood } \\
\text { loss }(\mathrm{ml}) \pm \text { SD }\end{array}$ & $\begin{array}{l}\text { Mean } \\
\text { operative } \\
\text { time(min) } \pm S \\
\text { D }\end{array}$ \\
\hline$<12$ & Abdominal & $312.77 \pm 25.45$ & $51.38 \pm 6.37$ \\
\cline { 2 - 4 } weeks & Vaginal & $284.75 \pm 29.04$ & $62.75 \pm 5.95$ \\
\hline $\begin{array}{l}\text { Z } \\
\text { weeks }\end{array}$ & Abdominal & $360.17 \pm 34.93$ & $50 \pm 5.0$ \\
\cline { 2 - 4 } Vaginal & $350 \pm 30.61$ & $76 \pm 8.21$ \\
\hline
\end{tabular}

Table 11: Volume reduction techniques used in vaginal hysterectomy.

\begin{tabular}{|llll|}
\hline Group & $\begin{array}{l}\text { Only } \\
\text { bisection }\end{array}$ & $\begin{array}{l}\text { Morcellation } \\
\text { with bisection } \\
\text { and } \\
\text { myomectomy }\end{array}$ & $\begin{array}{l}\text { Coring with } \\
\text { bisection and } \\
\text { myomectomy }\end{array}$ \\
\hline Vaginal & 12 & 08 & 01 \\
\hline Abdominal & No volume reduction techniques required. \\
\hline
\end{tabular}

Table 12: Operative complications and post-operative morbidity.

\begin{tabular}{|llll|}
\hline Complications & $\begin{array}{l}\text { Abdominal } \\
\text { N }(\%)\end{array}$ & $\begin{array}{l}\text { Vaginal } \\
\mathbf{N}(\%)\end{array}$ & p-value \\
\hline Bowel injury & 00 & 00 & - \\
\hline Bladder injury & 00 & 00 & - \\
\hline $\begin{array}{l}\text { Ureteric injury } \\
\text { injury }\end{array}$ & 00 & 00 & - \\
\hline Fever & $02(08 \%)$ & $01(04 \%)$ & $0.552, \mathrm{NS}$ \\
\hline $\begin{array}{l}\text { Urinary tract } \\
\text { infection }\end{array}$ & $01(04 \%)$ & $01(04 \%)$ & $\begin{array}{l}1.00, \\
\mathrm{NS}\end{array}$ \\
\hline $\begin{array}{l}\text { Vaginal cuff } \\
\text { cellulitis }\end{array}$ & $00(00 \%)$ & $01(04 \%)$ & $\begin{array}{l}0.312, \\
\mathrm{NS}\end{array}$ \\
\hline $\begin{array}{l}\text { Abdominal } \\
\text { wound infection } \\
\text { and resuturing }\end{array}$ & $02(08 \%)$ & - & $\begin{array}{l}0.419, \\
\mathrm{NS}\end{array}$ \\
\hline $\begin{array}{l}\text { Re-laparotomy } \\
\text { Conversition into }\end{array}$ & $\begin{array}{l}\text { Not }(00 \%) \\
\text { applicable }\end{array}$ & $00(00 \%)$ & - \\
\hline \begin{tabular}{l} 
abdominal \\
\hline
\end{tabular} & 1 & - \\
\hline
\end{tabular}

Table 13: Analgesics required after abdominal and vaginal hysterectomy.

\begin{tabular}{|lll|}
\hline Group & $\begin{array}{l}\text { Analgesies required } \\
\text { Mean days } \pm \text { SD }\end{array}$ & p-value \\
\hline Abdominal & $4.64 \pm 1.35$ & 0.0000, HS \\
\hline Vaginal & $2.52 \pm 0.65$ & \\
\hline
\end{tabular}


Table 14: Mean post-operative hospital stay in abdominal and vaginal.

\begin{tabular}{|lll|}
\hline Group & $\begin{array}{l}\text { Post-operative } \\
\text { hospital stay (Mean } \\
\text { days } \pm \text { SD) }\end{array}$ & $\mathrm{P}=$ value \\
\hline Abdominal & $9.04 \pm 3.61$ & $\mathrm{p}=0.0000, \mathrm{HS}$ \\
\hline Vaginal & $4.92 \pm 0.40$ & $\mathrm{~s}$ \\
\hline
\end{tabular}

Table 15: Return to routine work after abdominal and vaginal group.

\begin{tabular}{|llll|}
\hline $\begin{array}{l}\text { Return to } \\
\text { routine } \\
\text { work (days) }\end{array}$ & $\begin{array}{l}\text { Abdominal } \\
\mathbf{N}(\%)\end{array}$ & $\begin{array}{l}\text { Vaginal } \\
\mathbf{N}(\%)\end{array}$ & $\begin{array}{l}\text { Total } \\
\mathbf{N}(\%)\end{array}$ \\
\hline $7-14$ & $00(0 \%)$ & $01(04 \%)$ & $01(02 \%)$ \\
\hline $15-21$ & $10(40 \%)$ & $22(88 \%)$ & $32(64 \%)$ \\
\hline $22-28$ & $14(56 \%)$ & $02(08 \%)$ & $16(32 \%)$ \\
\hline$>28$ & $01(04 \%)$ & $00(0 \%)$ & $01(02 \%)$ \\
\hline Total & 25 & 25 & $50(100 \%)$ \\
\hline
\end{tabular}

Table 16: Mean days required to return to normal work.

\begin{tabular}{|c|c|c|}
\hline Group & $\begin{array}{l}\text { Return to normal work } \\
\text { (Mean days } \pm \text { SD) }\end{array}$ & $\mathbf{P}=$ value \\
\hline Abdominal & $25.24 \pm 5.19$ & \multirow{2}{*}{$\begin{array}{l}\mathrm{p}=0.0000, \\
\text { HS }\end{array}$} \\
\hline Vaginal & $17.96 \pm 3.33$ & \\
\hline
\end{tabular}

\section{DISCUSSION}

Benassi $\mathrm{L}$ et al in his trial 'Abdominal or vaginal hysterectomy for enlarged uteri: a randomized clinical trial' 60 vaginal hysterectomies were compared with 59 abdominal hysterectomies. ${ }^{7}$ All of the hysterectomies were med for symptomatic uterine fibroids. For enlarged uterus vaginal hysterectomies were performed with the use of volume reduction techniques like intramyometrial coring, bisection, and morcellation. There were no major differences in patient age, weight, parity, and uterine weight between the two groups. Operative time was significantly lower for the vaginal route as compared with the abdominal route (86 minutes versus 102 minutes, $\mathrm{P}$ $<0.001)$. No intra-operative complications were noted in both the routes. Intra-operative bleeding was not significantly different between the two groups. In the post-operative period a higher incidence of fever $(30.5 \%$ versus $16.6 \%, \mathrm{P}<0.05)$ and demand for analgesics $(86 \%$ versus $66 \%, \mathrm{P}<0.05)$ observed in the Group A as compared with the Group B. Reduction in the hospital stay ( 3 days versus 4 days, $\mathrm{P}<0.001$ ) was the significant advantage with vaginal hysterectomy over abdominal hysterectomy. According to the author choice for vaginal hysterectomy is a valid alternative to the abdominal hysterectomy even for enlarged uteri.

Kumar Sushil, Antony ZK determined the feasibility and safety of vaginal hysterectomy for benign nonprolapsed uteri. $^{8}$ Vaginal hysterectomy was done in 80 patients for benign uterine conditions with size of uterus between 6 to 16 weeks without adnexal disease. Parameters were similar to our study, operative blood loss between was in the range of $65 \mathrm{ml}$ to $600 \mathrm{ml}$. Time required to remove the uterus was between $40 \mathrm{~min}$ to $120 \mathrm{~min}$. Surgical techniques like morcellation, bisection and myomectomy were used for uterus size 8 to 16 weeks. Conversion to laparotomy was needed in four cases. Bisection (50\%) was the commonest procedure used. Vaginal hysterectomy was successful in 76 cases (95\%). Two patients had bladder injuries. Vault granuloma occurred in two patients. Author concluded that vaginal hysterectomy with enlarged uterus can be done safely up to 14 weeks. For uterus more than 14 weeks size it needs good experience and may be associated with more complications.

Sunanda Bharatnur comparative study 'abdominal hysterectomy versus vaginal hysterectomy in non-descent cases' studied the complications of abdominal and vaginal hysterectomies during intra-operative and postoperative period. ${ }^{9}$ Operations were done in cases with nonprolapsed uterus with good uterine mobility and uterine size less than 16 weeks. Out of 50 patients in the study 25 patients were operated for abdominal hysterectomy and 25 for vaginal hysterectomy, results were similar to our study.

\section{CONCLUSION}

Vaginal hysterectomy is safe and effective procedure for moderately enlarged uteri cases, with proper case selection and use of bulk reducing techniques like bisection, myomectomy, morcellation and coring hysterectomy by vaginal route is feasible in cases with enlarged uterus due to benign condition up to 14 weeks. Intraoperative blood loss and complications are less in vaginal hysterectomy as compared to abdominal hysterectomy for these cases. Less post-operative morbidity, shorter hospital stay and faster recovery indicates that the vaginal route should be the choice of operation for moderately enlarged uterine cases. Better training in vaginal techniques would most likely change the current preference for abdominal surgeries and lead gynaecologist to consider the vaginal approach as the standard route of surgery.

Funding: No funding sources

Conflict of interest: None declared

Ethical approval: The study was approved by the Institutional Ethics Committee

\section{REFERENCES}

1. Robert S. Kovac: Guidelines to determine the route of hysterectomy. Obstet and Gynecology. 1995;85(1):18-22.

2. Richardson RE, Bournas N, Magos AL. Is laparoscopic hysterectomy a waste of time? Lancet. 1995;345:36-41. 
3. Te Linde's Operative Gynaecology, Tenth Edition. Abdominal Hysterectomy. 733-739.

4. Te Linde's Operative Gynaecology, Tenth Edition Vaginal Hysterectomy. 745-755.

5. Bernstein SJ, McGlyn EA, Siu AL. The appropriateness of hysterectomy. A comparison of care in seven health plans. Health maintenance organization quality of care consortium. JAMA. 1993:269-2398.

6. Hoffman MS, DeCesare S, Kalter C. Abdominal hysterectomy versus transvaginalmorcellation for the removal of enlarged uteri. Am J Obstet Gynecol. 1994;171:309-13.
7. Benassi L, Rossi T, Kaihura CT, Ricci L, Bedocchi L, Galanti B. Abdominal or vaginal hysterectomy for enlarged uteri: a randomized clinical trial. Am J Obstet Gynecol. 2002;187:1561-65.

8. Sushil K, Antony ZK. Vaginal hysterectomy for benign nonprolapsed uterus. Initial Experience. J Obstet Gynaecol Ind. 2004;54(1):60-3.

9. Bharatnur S. A comparative study of abdominal versus vaginal hysterectomy in non-descent cases, Internet journal of gynecology and obstetrics. $2011 ; 15(2)$.

Cite this article as: Chandrika S, Kosti K. Comparative study of vaginal hysterectomy and abdominal hysterectomy for enlarged uterus. Int $\mathbf{J}$ Reprod Contracept Obstet Gynecol 2016;5:3116-20. 